\title{
Validitas Lembar Kerja Peserta Didik (LKPD) pada Materi Pertidaksamaan Linier Dua Variabel
}

\author{
Siti Hawa Siregar ${ }^{1 *}$, Siti Ramadhani Putri Zulham², Nurul Intan Nirwana ${ }^{3}$, Kamilah \\ Silalahi $^{4}$, \& Ibrahim Yusup Nasution ${ }^{5}$ \\ 1,2,3,4,5 Universitas Negeri Medan, Medan, Indonesia
}

\section{INFO ARTICLES}

Article History:

Received: 15-11-2021

Revised: $15-12-2021$

Approved: 17-12-2021

Publish Online: $31-12-2021$

Key Words:

Validity; Student Worksheet; Linear Inequality of Two Variables;

This article is licensed under a Creative Commons AttributionShareAlike 4.0 International License.

\begin{abstract}
This study aims to develop student worksheets (LKPD) on the material of linear inequalities of two variables that are suitable for use in learning activities. This type of research is Research and Development using the Plomp model. This plomp model consists of five stages in the implementation of its development, namely: 1. Investigation stage; 2. Design stage; 3. Realization stage; 4. Stages of testing, evaluation, and revision; and 5. Implementation phase. The data obtained were then analyzed descriptively quantitatively and also qualitatively. Based on the results of LKPD research and development, the validation results obtained $77.8 \%$ on the validation of the material in the valid category and $80 \%$ on the validation of the media with the valid category. So it is concluded that the development of LKPD on the material of linear inequalities of two variables developed using the Plomp model is valid for use in learning activities.
\end{abstract}

Abstrak: Penelitian ini bertujuan untuk mengembangkan lembar kerja peserta didik (LKPD) pada materi pertidaksamaan linier dua variabel yang layak untuk digunakan dalam kegiatan pembelajaran. Jenis penelitian ini adalah penelitian dan pengembangan atau Research and Development dengan menggunakan model Plomp. Model plomp ini terdiri atas lima tahapan dalam pelaksanaan pengembangannya, yaitu: 1 . Tahap investigasi; 2 . Tahap desain; 3. Tahap realisasi; 4. Tahap tes, evaluasi dan revisi; dan 5. Tahap implementasi. Data yang diperoleh kemudian dianalisis secara deskriptif kuantitatif dan juga kualitatif. Berdasarkan pada hasil penelitian dan pengembangan LKPD diperoleh hasil validasi $77,8 \%$ pada validasi materi dengan kategori valid dan hasil $80 \%$ pada validasi media dengan kategori valid. Sehingga disimpulkan bahwa pengembangan LKPD pada materi pertidaksamaan linier dua variable yang dikembangan dengan menggunakan model Plomp valid untuk digunakan dalam kegiatan pembelajaran.

Correspondence Address: Jln. Pandu V Blok R No. 4, Kab. Deli Serdang, Sumatera Utara, Indonesia, Kode Pos 20372; e-mail: sitihawa.29srg@gmail.com

How to Cite (APA $6^{\text {th }}$ Style): Siregar, S.H., dkk. (2021). Validitas Lembar Kerja Peserta Didik (LKPD) pada Materi Pertidaksamaan Linier Dua Variabel. JKPM (Jurnal Kajian Pendidikan Matematika), 7(1): 51-58. http://dx.doi.org/10.30998/jkpm.v7i1.11365

Copyright: 2021 Siti Hawa Siregar, Siti Ramadhani Putri Zulham, Nurul Intan Nirwana, Kamilah Silalahi, Ibrahim Yusup Nasution

Competing Interests Disclosures: The authors declare that they have no significant competing financial, professional or personal interests that might have influenced the performance or presentation of the work described in this manuscript. 


\section{PENDAHULUAN}

Matematika adalah metode berpikir dan bernalar yang dapat digunakan guna membuat keputusan terhadap kebenaran atau kesalahan atau paling tidak ada kemungkinan benar dari suatu ide tersebut (Ratriana, et. al., 2021). Matematika adalah ilmu pasti yang diperoleh melalui penalaran dalam aplikasinya dalam kehidupan sehari-hari dan hasil perhitungannya selalu pasti. Salah satu mata pelajaran yang selalu ada dalam setiap jenjang pendidikan adalah matematika (Hudha \& Irianto, 2021). Matematika mempunyai peranan yang sangat penting dalam berbagai aspek pengembangan daya pikir dan intelektual manusia. Karena itu, kematangan pemahaman matematika sangat penting untuk dikembangkan untuk menghadapi tantangan masa depan dalam proses pemecahan masalah dalam kehidupan sehari-hari (Saputri \& Zulkardi, 2020).

Secara bahasa, kata matematika (mathematics) berasal dari bahasa Yunani yaitu kata mathema yang mempunyai arti pengetahuan, atau dari kata lain yang serupa yaitu mathanein yang berarti belajar atau berpikir. Secara etimologis, matematika dapat diartikan sebagai pengetahuan yang diperoleh dengan berpikir (Aonillah, et. al., 2016). Matematika sering dianggap sebagai ilmu yang sulit untuk dipelajari mulai dari tingkat sekolah dasar bahkan sampai tingkat perguruan tinggi. Terlebih lagi, di masa pandemi ini pembelajaran yang dilakukan secara daring membuat suasana belajar kurang interaktif (Suciati, 2021). Berdasarkan Undang-Undang No. 20 tahun 2003 Pasal 1 Ayat 20 tentang Sisdiknas, dijelaskan bahwa pembelajaran merupakan sebuah proses interaksi antara peserta didik dengan pendidik yang menggunakan berbagai sumber belajar dan dilakukan pada suatu lingkungan belajar. Maka dari itu dapat disimpulkan bahwa pembelajaran ialah sebuah usaha dalam membuat kondisi dimana peserta didik belajar. Penggunaan media dalam proses pembelajaran dapat meningkatkan minat peserta didik untuk belajar.

Lembar kerja peserta didik (LKPD) dapat diartikan sebagai sarana untuk mengaktifkan murid atau peserta didik untuk belajar secara mandiri atau kelompok. LKPD biasanya digunakan oleh pendidik sebagai stimulus atau bimbingan dari pendidik tersebut dalam melaksanakan pembelajaran di sekolah (Septian, et. al., 2019). LKPD merupakan lembaran yang berisikan petunjuk dan langkah-langkah penyelesaian suatu aktivitas yang harus dilakukan oleh siswa. LKPD dikembangkan mengikuti kesesuaian dengan kebutuhan pembelajaran dari siswa. Dengan digunakannya LKPD dalam pembelajaran, siswa menjadi lebih aktif dalam kegiatan pembelajaran(Abdillah \& Astuti, 2020). Untuk membuat kegiatan pembelajatan yang lebih menarik maka pendidik atau guru lebih baik menggunakan suatu media pembelajaran sesuai dengan materi pembelajaran serta yang diharapkan mampu merangsang dan mendukung pemikiran siswa (Wynarti, 2018).

Guru harus mampu memberikan suatu alternatif media pembelajaran bagi siswa sehingga siswa dapat memahami konsep materi pembelajaran yang telah diajarkan (Andriyani, 2016). LKPD berfungsi sebagai suatu panduan pembelajaran bagi peserta didik dan juga berguna untuk mempermudah peserta didik dan juga guru dalam melakukan kegiatan belajar mengajar (Risfalidah, et. al., 2019; Apriliyani \& Mulyatna, 2021). Berdasarkan data dari Depdiknas pada tahun 2010, lembar kerja peserta didik atau LKPD berisi tugas yang diberikan pendidik untuk dikerjakan oleh peserta didik. Lembar kegiatan tersebut berisi petunjuk dan langkah-langkah untuk menyelesaikannya. Penggunaan LKPD dapat membantu peserta didik untuk belajar memahami secara mandiri dalam melaksanakan pembelajaran. Pembelajaran yang dilakukan dengan LKPD interaktif dapat menciptakan suasana belajar yang tidak membosankan dan menyenangkan bagi peserta didik, peserta didik dan pendidik pun tidak akan merasa tertekan saat melakukan proses pembelajaran, peserta didik tidak akan takut untuk bertanya dan tidak akan membuat peserta didik tegang (Lathifah et. al., 2021). LKPD yang dikembangkan sebaiknya memberi kesan menari bagi peserta didik seperti gambar dan tabel yang berkaitan dengan materi sehingga mendorong rasa penasaran dan ketertarikan untuk membaca LKPD tersebut (Jaya, et. al., 2019). 
Masih rendahnya hasil pembelajaran matematika yang merupakan salah satu bentuk indikasi bahwa tujuan yang ditentukan dalam kurikulum matematika belum tercapai secara optimal (Sulianto, 2008). Karena itu, tujuan tersebut dapat tercapai sesuai dengan yang diinginkan, salah satunya dengan melaksanakan suatu proses pembelajaran dengan berkualitas. Pembelajaran berkualitas dapat dilaksanakan dengan pembelajaran menggunakan alat bantu berupa media pembelajaran. Bahan ajar yang digunakan pada proses pembelajaran akan menentukkan kualitas pembelajaran yang dilaksanakan.

Guru sebagai tenaga pendidik diharapkan dapat mengembangkan bahan ajar yang baik sebagai salah satu sumber belajar dalam proses pembelajaran untuk melengkapi elemen dalam RPP. LKPD adalah salah satu bahan ajar dan sumber belajar yang juga berperan sebagai penunjang dalam proses pembelajaran mengajar. LKPD atau yang juga biasa dikenal dengan sebutan LKS (lembar kerja siswa) dapat digunakan untuk meminimalkan peran pendidik dalam proses pembelajaran serta dapat meningkatkan keaktifan peserta didik dalam proses pembelajaran. Lembar kegiatan ini biasanya berupa petunjuk disertai dengan langkahlangkah untuk menyelesaikan suatu tugas atau pemasalahan yang terdapat di dalam LKPD, dan tugas tersebut harus jelas kompetensi dasar yang akan dicapai melalui pelaksanaan tugas tersebut (Setiyaningsih, 2017). Berdasarkan uraian permasalahan di atas, maka tujuan penelitian ini adalah untuk mengembangkan LKPD pada materi Pertidaksamaan Linier Dua Variabel.

\section{METODE}

Metode penelitian dan pengembangan (research and development) merupakan metode penelitian yang digunakan untuk menghasilkan produk tertentu yang dalam hal penelitian ini, produk tersebut adalah LKPD dan untuk menguji keefektifan dari produk tersebut. Penelitian pengembangan adalah usaha untuk mengembangkan dan memvalidasi suatu produk yang digunakan dalam proses pembelajaran (Purnama, 2016). Research and Development adalah pengembangan yang sistematis mengenai cara merancang suatu produk, memproduksi atau mengembangkan produksi. Tujuannya adalah untuk mendapatkan data yang empiris dan juga bisa digunakan sebagai landasan atau dasar dalam membuat suatu alat dan produk yang dapat diterapkan dalam proses pembelajaran maupun nonpembelajaran (Fitri, et. al., 2021). Kegiatan penelitian digunakan untuk memperoleh informasi tentang kebutuhan pengguna dan dalam pelaksanaan uji coba produk ini, dan kegiatan pengembangan dilaksanakan untuk memperoleh atau menghasilkan suatu produk pembelajaran. Model penelitian yang digunakan dalam penelitian R\&D ini adalah model plomp (Tahapannya dapat dilihat dalam Gambar 1.). Model ini terdiri dari lima tahapan pengembangan, yaitu: 1. Tahap investigasi awal; 2. Tahap desain; 3. Tahap realisasi; 4. Tahap tes, evaluasi dan revisi; dan 5. Tahap implementasi (Siregar, et. al., 2020).

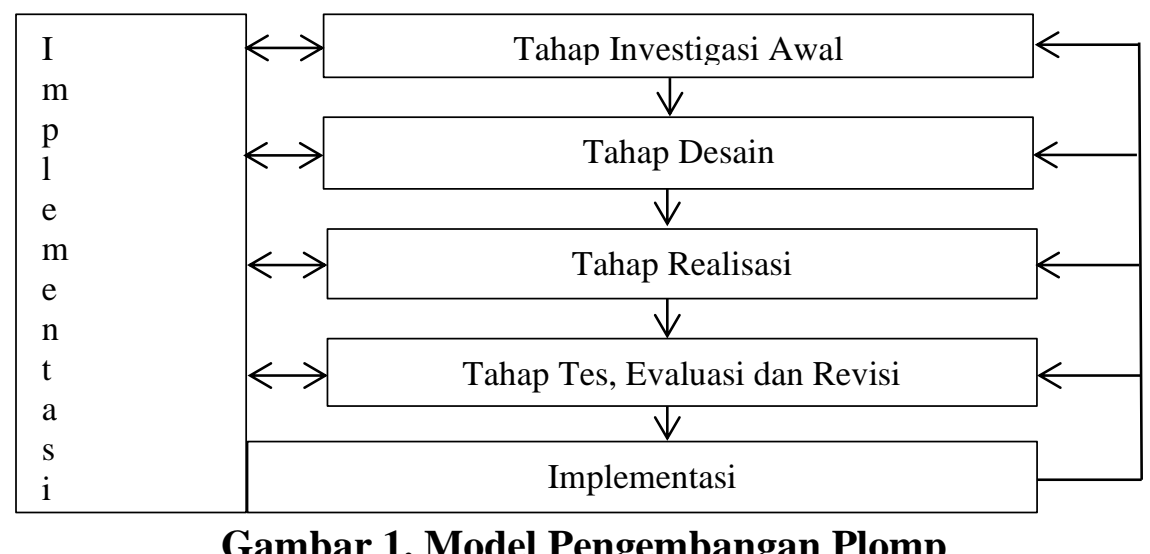

Gambar 1. Model Pengembangan Plomp 
Pada tahap investigasi awal, kegiatan dilakukan dengan menganalisis sumber tertulis, analisis konsep, analisis materi dan perumusan tujuan pembelajaran. Pada tahap desain, dilakukan penyusunan instrumen pembelajaran, pemilihan media dan format, serta peracancangan produk awal. Pada tahap realisasi dihasilkan bentuk dasar dari produk sebagai hasil dari realisasi dari tahap desain. Pada tahap tes, evaluasi dan revisi, dilakukan validasi kepada ahli materi dan ahli media. Pada tahap implementasi adalah penyebaran produk yang dikembangkan. Namun, pada penelitian ini, tahapan penelitian hanya dibatasi sampai pada tahap validasi oleh para validator.

Teknik pengumpulan data LKPD diperoleh melalui lembar validasi yang diberikan kepada para validator mengenai validasi materi dan validasi media. Validasi materi terdari atas tiga aspek, meliputi aspek kelayakan isi materi, aspek peyajian dan aspek kebahasaan yang dilakukan oleh guru matematika. Sedangkan, validasi media terdiri dari tiga aspek, yaitu aspek ukuran LKPD, aspek kelayakan jenis kertas LKPD, aspek gambar isi LKPD, aspek efisiensi LKPD dan aspek desain tampilan yang dilakukan oleh valiator yang berjumlah 3 (tiga) orang yang merupakan guru matematika di SMA Negeri 1 Hamparan Perak.

Selanjutnya, data yang telah diperoleh dari validasi ahli materi dan validasi ahli media kemudian disajikan dengan skala Likert dan dianalisis lebih lanjut untuk mencari nilai kelayakan dari produk tersebut dengan menggunakan rumus berikut:

$$
\mathrm{K}=\frac{\mathrm{F}}{\mathrm{N} . \mathrm{I} . \mathrm{R}} \times 100 \%
$$

Keterangan: $\mathrm{K}=$ Persentasi kelayakan; $\mathrm{F}=$ Jumlah seluruh jawaban responden; $\mathrm{N}=$ Skor tertinggi dalam angket; I = Jumlah pertanyaan dalam angket; $\mathrm{R}=$ Jumlah responden (Siregar, et. al., 2020).

Rata-rata dari persentasi yang didapatkan selanjutnya akan disesuaikan dengan kriteria menggunakan ketentuan berikut: a. Rentang skor adalah 1-4; b. Kriteria penilaian dibagi atas empat tingkatan, yaitu: sangat valid, valid, kurang valid, tidak valid; dan c. Rentang skor terbagi menjadi empat kelas interval. Adapun penetapan tingkat validitas tersebut ditentukan berdasarkan kriteria yang ada dalam Tabel 1. .

Tabel 1. Kriteria Kelayakan LKPD

\begin{tabular}{ll} 
Tingkat Pencapaian & Kategori \\
$85,01 \%<\mathrm{x}<100 \%$ & Sangat Valid \\
$70,01 \%<\mathrm{x}<85 \%$ & Valid \\
$50,01 \%<\mathrm{x}<70 \%$ & Kurang Valid \\
$01,00 \%<\mathrm{x}<50 \%$ & Tidak Valid \\
\hline
\end{tabular}

Sumber: (Siregar, et. al., 2020)

\section{HASIL}

Pada tahap investigasi awal, kegiatan dilakukan dengan menganalisis sumber tertulis, analisis konsep, materi tujuan pembelajaran dari pertidaksamaan linier dua variabel. Pada tahap desain, produk ini didesain dengan menggunakan Ms. Word untuk mendesain dan mengatur posisi dan tata letak dari seluruh komponen LKPD, kemudian digunakan tambahan berupa gambar dan ilustrasi lainnya yang dapat memperindah LKPD sehingga mendorong rasa penasaran dan ketertarikan untuk membaca LKPD tersebut. Selanjutnya, tahap realisasi merupakan tahap lanjutan dari tahap desain dan pada tahap ini dihasilkan sebuah produk, yaitu lembar kerja peserta didik sebagai realisasi dari tahap desain. Pada tahap tes, evaluasi dan revisi, validator materi berjumlah 3 (orang) dan validator media yang juga berjumlah 3 (tiga) orang melakukan validasi 
terhadap lembar kerja peserta didik yang dihasilkan dan memberikan komentar/saran serta revisinya terhadap produk tersebut.

Indikator dari validasi materi terdiri atas tiga aspek, meliputi aspek kelayakan isi materi, aspek peyajian dan aspek kebahasaan yang dilakukan oleh 3 (tiga) orang guru matematika di SMA Negeri 1 Hamparan Perak. Sedangkan, indikator validasi media terdiri dari tiga aspek, yaitu aspek ukuran LKPD, aspek kelayakan jenis kertas LKPD, aspek gambar isi LKPD, aspek efisiensi LKPD dan aspek desain tampilan yang dilakukan oleh valiator yang berjumlah 3 (tiga) orang yang merupakan guru matematika di SMA Negeri 1 Hamparan Perak. Hasil persentase ini kemudian disesuaikan dengan kriteria kelayakan LKPD pada Tabel 1.. Hasil perhitungan validasi ahli materi dan media disajikan dalam Tabel 2.

Tabel 2. Hasil Validasi LKPD oleh Validator

\begin{tabular}{clll}
\hline & Validasi & Hasil Validasi & Keterangan \\
\hline Lembar Kerja & Materi & $77,8 \%$ & Valid \\
Peserta Didik (LKPD) & Media & $80 \%$ & Valid \\
\hline
\end{tabular}

Sumber: diolah dari data penelitian, 2021

Berdasarkan pada hasil penelitian dan pengembangan LKPD diperoleh hasil validasi $77,8 \%$ pada validasi materi dengan kategori valid dan hasil $80 \%$ pada validasi media dengan kategori valid. Penilaian dari validator menunjukkan bahwa LKPD ini sudah cukup valid dalam hal materi dan media dan layak untuk digunakan dalam pembelajaran materi pertidaksamaan linier dua variabel.

Hasil validasi ini digunakan sebagai acuan untuk melaksanakan tahapan revisi terhadap LKPD yang dikembangkan. Untuk materi dan media, revisi dilakuakn berdasarkan saran dan revisi tertulis yang diberikan oleh validator. Selain penilaian dalambentuk angka, validator juga memberikan komentar, saran dan revisi terhadap LKPD untuk perbaikan. Komentar/Saran dan revisi yang diberikan oleh validator dirangkum pada Tabel 3.

Tabel 3. Komentar/Saran dan Revisi Perbaikan dari Validator

\begin{tabular}{|c|c|c|}
\hline Validasi & Komentar/Saran & Jumlah \\
\hline Materi & $\begin{array}{l}\text { Isi yang dipaparkan sudah cukup baik dan tertata; } \\
\text { Isi pada LKPD yang terlampir sudah layak } \\
\text { diberikan kepada peserta didik; Penyajian sudah } \\
\text { cukup baik; Bahasa yang digunakan sudah valid dan } \\
\text { cukup mudah dipahami oleh peserta didik; Bentuk } \\
\text { soal/contoh soal lebih baik dalam bentuk cerita. }\end{array}$ & $\begin{array}{l}\text { Harap membuat daftar isi, } \\
\text { halaman serta daftar pustaka; } \\
\text { Tambahkan latihan soal; Pebaiki } \\
\text { tanda pertidaksamanan pada } \\
\text { contoh soal tertulis persamaan. }\end{array}$ \\
\hline Media & $\begin{array}{l}\text { Ukuran LKPD sudah sesuai; Kelayakan jenis kertas } \\
\text { LKPD sudah sesuai; Tata letak isi LKPD sudah } \\
\text { sesuai; LKPD yang terlampir sudah efisien, namun } \\
\text { pembaca sedikit kesulitan mencari apa yang ingin } \\
\text { dicari pada LKPD karena tidak terdapat daftar isi; } \\
\text { Tampilan desain sudah sangat menarik. }\end{array}$ & $\begin{array}{l}\text { Tambahkan daftar isi dan } \\
\text { halaman pada LKPD terlampir. }\end{array}$ \\
\hline
\end{tabular}

Sumber: diolah dari data penelitian, 2021

\section{PEMBAHASAN}

Validasi materi dilakukan untuk mendapatkan materi yang valid di dalam lembar kerja peserta didik (LKPD) yang dikembangkan. Sedangkan, validasi media dilakukan untuk memperoleh media LKPD yang 
valid. LKPD melalui proses validasi materi dan validasi media yang melibatkan ahli materi dan ahli media. Data validasi materi didapatkan dengan memberikan lembar validasi yang meliputi tiga aspek yaitu aspek kelayakan isi, peyajian dan bahasa kepada validator. Ahli materi diberikan produk yang dikembangkan kemudian melihat dan menganalisisnya, memberikan penilaian pada lembar validasi dan memberikan komentas/saran dan revisinya. Data validasi media didapatkan dengan memberikan lembar validasi yang meliputi lima aspek yaitu aspek ukuran LKPD, aspek kelayakan jenis kertas LKPD, gambar isi LKPD, efisiensi LKPD dan desain tampilan kepada validator. Ahli media diberikan produk yang dikembangkan kemudian melihat dan menganalisisnya, memberikan penilaian pada lembar validasi dan memberikan komentas/saran dan revisinya.

Penilaian dari validator menunjukkan bahwa LKPD ini sudah cukup valid dalam hal materi dan media dan layak untuk digunakan dalam pembelajaran materi pertidaksamaan linier dua variabel untuk kegiatan pembelajaran. Seluruh aspek penilaian dalam validasi materi sudah dinilai valid oleh validator dan layak untuk digunakan dan diberikan kepada peserta didik. Sedangkan untuk aspek penilaian pada validasi media, dari lima aspek penilaian, hanya terdapat satu aspek yang perlu diperbaiki dan secara keseluruhan telah dikatakan layak digunakan.

Berdasarkan hasil validasi oleh validator, untuk validasi materi, secara keseluruhan, Isi yang dipaparkan sudah cukup baik dan tertata; Isi pada LKPD yang terlampir sudah layak diberikan kepada peserta didik; Penyajian sudah cukup baik; Bahasa yang digunakan sudah valid dan cukup mudah dipahami oleh peserta didik; Bentuk soal/contoh soal lebih baik dalam bentuk cerita. Setelah itu, para validator juga memberikan revisi agar membuat daftar isi, halaman serta daftar pustaka; menambahkan latihan soal; dan memperbaiki tanda pertidaksamanan pada contoh soal tertulis persamaan.

Untuk validasi isi, secara keseluruhan ukuran LKPD sudah sesuai, kelayakan jenis kertas LKPD sudah sesuai, tata letak isi LKPD sudah sesuai, LKPD yang terlampir sudah efisien, namun pembaca sedikit kesulitan mencari apa yang ingin dicari pada LKPD karena tidak terdapat daftar isi, tampilan desain sudah sangat menarik. Revisi yang diberikan juga menekankan pada penambahan daftar isi dan halaman pada LKPD terlampir.

Saran-saran yang diberikan seperti tertera dalam Tabel 3. akan digunakan sebagai acuan dan pertimbangan dalam melakukan perbaikan pada LKPD yang dikembangkan, penyesuaian-penyesuaian banyak dilakukan sesuai dengan komentar/saran dan revisi yang diberikan oleh validator agar LKPD yang dihasilkan sebagai produk akhir dari pengembangan ini tidak hanya layak digunakan, namun juga tepat digunakan dan diterapkan dalam kegiatan pembelajaran serta dapat berfungsi sebagai suatu panduan pembelajaran bagi peserta didik dan juga berguna untuk mempermudah peserta didik dan juga guru dalam melakukan kegiatan belajar mengajar (Septian, et. al., 2019; Risfalidah, et. al., 2019).

\section{SIMPULAN}

Berdasarkan pada hasil dan pembahasan penelitian diperoleh simpulan penelitian ini yaitu LKPD materi pertidaksamaan linier dua variabel yang dikembangkan memenuhi kriteria kevalidan berdasarkan pada penilaian yang dilakukan oleh validator yang merupakan ahli materi dan ahli media. Validitas untuk LKPD yang dikembangkan, berdasarkan pada penilaian validator ahli materi dan media adalah $77,8 \%$ untuk materi dan $80 \%$ untuk media, yang berarri bahwa materi dan media LKPD berada pada kategori valid. Revisi yang dilakukan berfokus pada bagian pembuatan daftar isi, nomor halaman dan daftar pustaka. Secara keseluruhan, validator menyatakan bahwa LKPD yang dikembangkan sudah sesuai dan layak diberikan kepada peserta didik. 


\section{DAFTAR RUJUKAN}

Abdillah, D. M., \& Astuti, D. (2020). Pengembangan lembar kerja peserta didik (LKPD) berbasis problembased learning (PBL) pada topik sudut. Pythagoras: Jurnal Pendidikan Matematika, 15(2), 190-200. https://doi.org/https://doi.org/10.21831/pg.v15i2.36444 P

Andriyani, R. (2016). Pengembangan Lembar Kerja Siswa (LKS) Kemampuan Komunikasi Matematis Pada Materi Segiempat dan Segitiga Untuk Siswa SMP Kelas VII. AlphaMath Journal of Mathematics Education, 2(2). https://doi.org/10.30595/alphamath.v2i2.1229

Aonillah, D. R., Suherman, U., \& Nanang. (2016). PERBEDAAN MOTIF DAN KOMPETENSI DASAR MATEMATIKA PESERTA DIDIK KELAS VII MTs YPI AL-ULFAH ANTARA YANG MENGGUNAKAN MULTIMEDIA INTERAKTIF DENGAN. JTEP-Jurnal Teknologi Pendidikan Dan Pembelajaran, 1(1), 132-141. https://doi.org/https://doi.org/10.31980/tp.v1i1.103

Apriliyani, S. W., \& Mulyatna, F. (2021). Flipbook E-LKPD dengan Pendekatan Etnomatematika pada Materi Teorema Phytagoras. Prosiding Seminar Nasional Sains, 2(1), 491-500. http://www.proceeding.unindra.ac.id/index.php/sinasis/article/view/5389

Fitri, A., Netriwati, N., \& Andriani, S. (2021). Sigil Software sebagai Pengembangan E-Modul Pembelajaran Matematika. AlphaMath: Journal of Mathematics Education, 7(1), 1-10. https://doi.org/10.30595/alphamath.v7i1.8492

Hudha, T. T., \& Irianto, S. (2021). Almufi Jurnal Pendidikan ( AJP ) Pengembangan LKPD Matematika dalam Kegiatan Belajar Siswa Bersama Orang Tua Materi Keliling dan Luas Bangun Datar dengan. Almufi Jurnal Pendidikan (AJP), 1(2), 78-86. http://almufi.com/index.php/AJP/article/view/29

Jaya, S., Maizora, S., \& Muchlis, E. E. (2019). Pengembangan Lkpd Dengan Pendekatan Saintifik Di Sma Negeri 4 Kota Bengkulu. Jurnal Penelitian Pembelajaran Matematika Sekolah (JP2MS), 3(3), 285292.

Lathifah, M. F., Hidayati, B. N., \& Zulandri, Z. (2021). Efektifitas LKPD Elektronik sebagai Media Pembelajaran pada Masa Pandemi Covid-19 untuk Guru di YPI Bidayatul Hidayah Ampenan. Jurnal Pengabdian Magister Pendidikan IPA, 4(2), 25-30. https://doi.org/10.29303/jpmpi.v4i2.668

Purnama, S. (2016). Metode Penelitian Dan Pengembangan (Pengenalan Untuk Mengembangkan Produk Pembelajaran Bahasa Arab). LITERASI (Jurnal Ilmu Pendidikan), IV(1), 19-32. https://doi.org/10.21927/literasi.2013.4(1).19-32

Ratriana, D., Purwoko, R. Y., \& Yuzianah, D. (2021). Pengembangan E-modul Berbasis Etnomatematika yang Mengeksplorasi Nilai dan Budaya Islam untuk Siswa SMP. AlphaMath : Journal of Mathematics Education, 7(1), 11-19. https://doi.org/10.30595/alphamath.v7i1.8498

Risfalidah, Rosidin, U., \& Sutiarso, S. (2019). Pengembangan LKPD Berbasis Problem Based Learning Ditinjau dari Disposisi dan Kemampuan Komunikasi Matematis. JPPM (Jurnal Penelitian Dan Pembelajaran Matematika), 12(2), 271-283. http://repository.lppm.unila.ac.id/20065/

Saputri, N. W., \& Zulkardi, Z. (2020). Pengembangan LKPD Pemodelan Matematika Siswa SMP Menggunakan Konteks Ojek Online. Jurnal Pendidikan Matematika, 14(1), 1-14. https://doi.org/https://doi.org/10.22342/jpm.14.1.6825.1-14

Septian, R., Irianto, S., \& Andriani, A. (2019). Pengembangan Lembar Kerja Peserta Didik (Lkpd) Matematika Berbasis Model Realistic Mathematics Education. Jurnal Educatio FKIP UNMA, 5(1), 59-67. https://doi.org/https://doi.org/10.31949/educatio.v5i1.56

Setiyaningsih, D. (2017). Pengembangan Lembar Kerja Peserta Didik (LKPD) Matematika SMK Berbasis Saintifik. Ekuivalen-Pendidikan Matematika, 30(3), 255-260.

Siregar, T. B., Putri, A. N., \& Hindrasti, N. E. K. (2020). VALIDITAS LEMBAR KERJA PESERTA DIDIK (LKPD) BERBASIS PROBLEM BASED LEARNING PADA MATERI SISTEM EKSKRESI 
UNTUK SISWA KELAS VIII SMP. Jurnal Pendidikan Dan Pembelajaran Sains Indonesia (JPPSI), 3(2), 130-139. https://doi.org/http://dx.doi.org/10.23887/jppsi.v3i2.28577

Suciati, P. (2021). School From Home (SFH): Perjuangan Para Orang Tua Siswa Usia Dini di Masa Pandemi Covid-19. Jurnal Sosial Humaniora Terapan, 3(2), 7-16.

Sulianto, J. (2008). Pendekatan Kontekstual Dalam Pembelajaran Matematika Untuk Meningkatkan Berpikir Kritis Pada Siswa Sekolah Dasar. Pythagoras: Jurnal Pendidikan Matematika, 4(2), 14-25. https://doi.org/https://doi.org/10.21831/pg.v4i2.555

Undang-Undang RI No. 20 Tahun 2003 tentang Sisdiknas.

Wynarti, I. A. (2018). Pengembangan Permainan Charades Sebagai Media Pembelajaran Materi Jenis-jenis Bisnis Ritel Kelas XI Pemasaran Di SMK Negeri 2 Buduran. Jurnal Pendidikan Tata Niaga (JPTN), 6(2), 63-70. https://ejournal.unesa.ac.id/index.php/jptn/article/view/24255 